$S P R I N G$

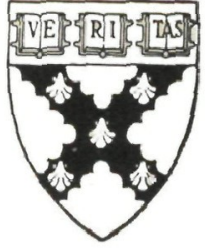

FEATURED IN THIS ISSUE

- Watchmaking Enterprise

- Ruhr Industrialists before World War

- Upper Silesian and Ruhr Industrialists Compared

- The Value of Company History

- edITOR'S CORNER

- BOOK REVIEWS 


\section{ADVISORY BOARD}

EOITOR

ALBRO MARTIN

Lecturer in

Business History

Harvard University

\section{ASSOCIATE EDITOR}

HELEN FREY ROCHLIN

Harvard University
FRED BATEMAN

Professor of

Business Economics

Indiana University

JAMES P. BAUGHMAN

Professor of

Business Administration

Harvard University

STUART W. BRUCHEY

Allan Nevins Professor of American Economic History

Columbia University

ALFRED D. CHANDLER, JR.

Straus Professor of

Business History

Harvard University

FRANCOIS CROUZET

Professor of History

University of Paris, Sorbonne

STANLEY ENGERMAN

Professor of Economics

University of Rochester

LESLIE HANNAH

Director

Business History Unit

London School of

Economics \& Political Science
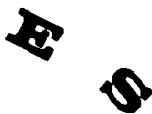

ELLIS W. HAWLEY

Professor of History

University of Iowa

MORTON KELLER

Spector Professor of History

Brandeis University

JÜRGEN KOCKA

Faculty of History

University of Bielefeld

HAROLD C. LIVESAY

Professor of History

SUNY-Binghamton

THOMAS K. MC CRAW

Professor of Business

Administration

Harvard University

GARY JOHN PREVITS

Professor of Accounting University of Alabama

S. B. SAUL

Vice-chancellor

University of York

MERRITT ROE SMITH

Professor of the History of Technology

Massachusetts Institute of Technology

PAUL USELDING

Professor of Economics

University of Illinois

KOZO YAMAMURA

Professor of Economics

University of Washington

\section{HONORARY MEMBER}

HENRIETTA M. LARSON

Professor of

Business History

Harvard University [Emerita] 


\section{BUSINESS HISTORY REVIEW}

$\begin{array}{llllllll}C & O & N & T & E & N & T & S\end{array}$

WATCHMAKING: A CASE STUDY IN ENTERPRISE AND CHANGE

DAVID S. LANDES

RULERS OF THE RUHR: LEADERSHIP AND AUTHORITY IN

GERMAN BIG BUSINESS BEFORE 1914 . . . . .

ELAINE GLOVKA SPENCER

ENTREPRENEURS IN HEAVY INDUSTRY: UPPER SILESIA AND

THE WESTPHALIAN RUHR REGION, 1852 TO 1913 . .

TONI PIERENKEMPER

THE VALUE OF COMPANY HISTORY: A REVIEW ARTICLE .

THOMAS C. COCHRAN

THE EDITOR'S CORNER

\section{BOOK REVIEWS}

Adams, Donald R., Finance and Enterprise in Early America: A Study of Stephen Girard's Bank, 1812-1831. Reviewed by John A. James .

Akin, William E., Technocracy and the American Dream, The Technocrat Movement, 1900-1941 Reviewed by Edwin T. Layton

Alperin, Lynn M., Custodians of the Coast: History of the United States Army Engineers at Galveston. Reviewed by Joe Pratt .

Ball, Mia, The Worshipful Company of Brewers: A Short History. Reviewed by William F. Kahl .

Barnouw, Erik, The Sponsor: Notes on a Modern Potentate. Reviewed by Richard S. Tedlow . . . . . . . .

Bartlett, J. Neville, Carpeting the Millions: The Growth of Britain's Carpet Industry. Reviewed by Nancy P. Norton . .

Benjamin, Jules Robert, The United States and Cuba: Hegemony and Dependent Development, 1880-1934. Reviewed by Robert L. Beisner

(continued on next page)

PUBLISHED QUARTERLY BY THE HARVARD GRADUATE SCHOOL OF BUSINESS ADMINISTRATION 


\section{$\begin{array}{llllllll}C & O & N & T & E & N & T & S\end{array}$}

(continued)

Beyerchen, Alan D., Scientists Under Hitler: Politics and the Physics Community in the Third Reich. Reviewed by Margaret B. W. Graham . . . . . . . . . . • • .

Bodnar, John E., Immigration and Industrialization: Ethnicity in an American Mill Town, 1870-1940 Reviewed by Richard L. Ehrlich

Chao, Kang, The Development of Cotton Textile Production in China. Reviewed by Bruce L. Reynolds .

Chazanof, William, Welch's Grape Juice: From Corporation to Co-Operative. Reviewed by Daniel Pope

Cipolla, Carlo M., Before the Industrial Revolution: European Society and Economy, 1000-1700. Reviewed by Edward P. Duggan

Cipolla, Carlo M., ed., Contemporary Economies. Part One and Part Two. Reviewed by Mira Wilkins . . . . . .

Cipolla, Carlo M., ed., The Twentieth Century. Part One and Part Two. Reviewed by Paul M. Hohenberg. . . . . .

Dreher, Carl, Sarnoff: An American Success. Reviewed by Leonard S Reich . . . . . . . . . . . . .

Dick, Trevor J. O., Economic History of Canada: A Guide to Information Sources Reviewed by Donald G. Paterson. . .

128

102

140

111

108

104

152

Donovan, Robert J., Confict and Crisis: The Presidency of Harry S. Truman, 1945-1948. Reviewed by Thomas G. Paterson .

101

Foner, Philip S., ed., The Factory Girls: A Collection of Writings on Life and Struggles in the New England Factories of the 1840 s by the Factory Girls Themselves, and the Story, in Their Own Words, of the First Trade Unions of Women Workers in the United States. Reviewed by Susan Estabrook Kennedy .

Gillingham, John, Belgian Business in the Nazi New Order. Reviewed by Jos Delbeke.

Griffin, A. R., The British Coalmining Industry: Retrospect and Prospect. Reviewed by Charles K. Hyde . . . . . .

Hardach, Gerd, The First World War 1914-1918. Reviewed by Ulrich Nocken . . . . . . . . . . . . .

Hassinger, Edward W., The Rural Component of American Society. Reviewed by Allan G. Bogue .

Hilton, Boyd, Corn, Cash, Commerce: The Economic Policies of the Tory Governments 1815-1830. Reviewed by Ronald K. Huch

Hirschman, Albert O., The Passions and the Interests: Political Arguments for Capitalism Before its Triumph. Reviewed by D. T. Armentano .

Kirby, M. W., The British Coalmining Industry, 1870-1946. A Political and Economic History. Reviewed by Charles K. Hyde 


\section{$\begin{array}{llllllll}C & O & N & T & E & N & T & S\end{array}$}

(continued)

Klein, Herbert S., The Middle Passage: Comparative Studies in the Atlantic Slave Trade. Reviewed by B. W. Higman .

Kocka, Jürgen, Angestellte zwischen Faschismus und Demokratie. Zur politischen Sozialgeschichte der Angestellten: USA 18901940 im internationalen Vergleich. Reviewed by Hans Jaeger .

113

Lapp, Rudolph M., Blacks in Gold Rush California. Reviewed by Ernest S. Sweeney

Levine, David, Family Formation in an Age of Nascent Capitalism. Reviewed by William H. Mulligan, Jr.

Norton, Hugh S., The Employment Act and the Council of Economic Advisers, 1946-1976. Reviewed by Saul Engelbourg .

Platt, D. C. M., ed., Business Imperialism 1840-1930: An Inquiry Based on British Experience in Latin America. Reviewed by Laura Randall

Randall, Laura, An Economic History of Argentina in the Twentieth Century. Reviewed by Jonathan C. Brown . . . . .

Rice, Bradley Robert, Progressive Cities: The Commission Government Movement in America, 1901-1920. Reviewed by Zane L. Miller

Rodgers, Daniel T., The Work Ethic in Industrial America: 1850-1920. Reviewed by William Graebner .

Roethlisberger, F. J., The Elusive Phenomena: An Autobiographical Account of My Work in the Field of Organizational Behavior at the Harvard Business School. Reviewed by Daniel Nelson

Rosen, Elliot A., Hoover, Roosevelt, and the Brains Trust: From Depression to New Deal. Reviewed by Alonzo L. Hamby . .

Safford, Jeffrey J., Wilsonian Maritime Diplomacy 1913-1921. Reviewed by Ronald E. Coons

Stone, Lawrence, The Family, Sex and Marriage in England 1500-1800. Reviewed by Stanley L. Engerman . . . .

Trebilcock, Clive, The Vickers Brothers: Armaments and Enterprise, 1854-1914. Reviewed by Malcolm Smith .

Tugwell, Rexford G., Roosevelt's Revolution: The First YearA Personal Perspective. Reviewed by Harvard Sitkoff .

White, John H., The American Railroad Passenger Car. Reviewed by Keith L. Bryant, Jr. . . . . . • . . • . .

Wilson, William H., Railroad in the Clouds: The Alaska Railroad in the Age of Steam, 1914-1945. Reviewed by Donovan L. Hofsommer

Winkler, Allan M., The Politics of Propaganda: The Office of War Information, 1942-1945. Reviewed by Richard S. Tedlow . 


\section{REPRINTS AVAILABLE}

\section{Business History Review}

Formerly: Bulletin of the Business

Historical Society, Boston

Vols. 1-43 and Gen. Ind. 1-30. Boston,

Mass., 1926-1969

Vols. $1-30$ (in 15 units) *

Vols. $31-43$

General Index

General Index 28-30

cloth $\$ 923.00$

paper $\$ 749.00$

per unit paper $\$ 25.00$

per vol. paper $\$ 28.00$

paper $\$ 7.00$

paper $\$ 3.00$

- Vols. 1-24 reprinted in units as follows:

$1 / 3(1926-29) ; 4 / 6(1930-32) ; 7 / 9(1933-35)$;

$10 / 12(1936-38) ; 13 / 15(1939-41) ; 16 / 18(1942-44)$;

$19 / 20(1945-46) ; 21 / 22(1947-48) ; 23 / 24(1949-50)$.

\section{Journal of Economic and Business History}

Vols. 1-4(all publ.). Cambridge, Mass., 1928/29-1931/32.

Order from:

per vol. paper $\$ 35.00$

\section{KRAUS REPRINT CO}

A U.S. Division of Kraus-Thomson Organization Limited

Route 100

Millwood, New York 10546

The Business History Review (ISSN0007-6805) is published in the Spring, Summer, Autumn, and Winter. Address all communications, including manuscripts, change of address, and rights and permissions inquiries to Business History Review, 215 Baker Library, Soldiers Field, Boston, Massachusetts 02163. Telephone 617-495-6534. Individual subscription rate, $\$ 15.00$; Institutions, $\$ 20.00$. Special subscription rate for students, $\$ 5.00$. All subscriptions outside the U.S.A. and Canada, $\$ 20.00$. Back issues and reprints of current articles also available; rates on request. Notice of failure to receive issues must reach this office not later than six months after date of mailing.

The Business History Review does not assume responsibility for statements of fact or opinion made by its contributors.

The Business History Review Five-Year Indexes: Volume XXXVI (1962) Through Volume XL (1966); Volume XLI (1967) Through VolUME XLV (1971); and Volume XLVI (1972) Through Volume L (1976), can be obtained from our office at $\$ 4.00$ each, postpaid. These guides provide detailed author, title, proper name, and subject entries to our articles, notes and reviews over their period of coverage.

Contents are currently indexed or abstracted in: Accountants' Index; America: History and Life; Book Review Index; Book Review Index to Social Science Periodicals, Business Methods Index; Business Periodicals Index; Current Contents; Behavioral, Social, and Management Sciences; Historical Abstracts; Index to Economic Journals; Journal of Economic Literature; Public Affairs Information Service Bulletin; and Social Sciences Index. Second-class postage paid at Boston, Massachusetts. Printed at Harvard University Printing Office.

Copyright $(\mathcal{C} 1979$ by the President and Fellows of Harvard College. 